\title{
The Mask Stripped Bare by its Curators: The Work of Hybridity in the Twenty-First Century
}

Ruth B. Phillips

\section{(2) OpenEdition \\ Journals}

Édition électronique

URL : http://journals.openedition.org/actesbranly/336

DOI : 10.4000/actesbranly.336

ISSN : 2105-2735

Éditeur

Musée du quai Branly Jacques Chirac

Référence électronique

Ruth B. Phillips, "The Mask Stripped Bare by its Curators: The Work of Hybridity in the Twenty-First Century », Les actes de colloques du musée du quai Branly Jacques Chirac [En ligne], 1 | 2009, mis en ligne le 28 juillet 2009, consulté le 08 septembre 2020. URL : http://journals.openedition.org/ actesbranly/336 ; DOI : https://doi.org/10.4000/actesbranly.336

Ce document a été généré automatiquement le 8 septembre 2020

(C) Tous droits réservés 


\title{
The Mask Stripped Bare by its Curators: The Work of Hybridity in the Twenty-First Century
}

\author{
Ruth B. Phillips
}

1 I begin this paper, which addresses relationships among art history, anthropology, and museology in the first decade of the twenty-first century, by recalling an anecdote from my fieldwork in Sierra Leone in the 1970s. It bears retelling three decades later because it suggests what has changed and not changed in the intervening years, both in the practices of academic art historians and anthropologists and in the museum representations for which their disciplines are, ultimately, held accountable. My dissertation on Mende women's masks focused on classical art historical problems of iconographic interpretation and stylistic development and in preparation for my fieldwork I studied collections of Mende masks in major European and North American museums. In Sierra Leone, I travelled from village to village, observing masquerade performances, interviewing people about ritual context, and asking to see and document the carved headpieces then in use by Sande Society masqueraders.

2 My focus on the carved headpiece, however, proved to be very un-Mende, and it immediately led to a problem of translation. The Mende, like most African peoples, do not have a separate word for "mask," for to speak of the headpiece separately from the rest of the masquerade costume, or to articulate the masked being's identity as an ngafa, or spirit, as separable from the material and mechanical components of its dramatic realization by a human impersonator, implies a distinction which the Mende do not verbalize in public discourse. I learned that the phrase that most closely translates the English "sowei mask" is sowo wui ("the head of sowei"). In more "modern" villages, the Sande women did not object to my seeing, measuring, and studying these "heads"-although sometimes in an enclosed area that men could not enter. In villages in which traditional protocols were more strictly observed, however, the Sande women brought out the fully masked and costumed figures, each accompanied by her attendants and heralded by the musical, high-pitched chanting of her name. Early on in 
my fieldwork, I tried to explain to the chief who had arranged my meeting with Sande women in one of these more traditional villages that it wasn't necessary for my needs to go to all the trouble of "pulling" the whole masquerade. He gently responded that the ndoli sowei could only be seen when fully and correctly garbed, and to drive home the point he asked me: "Could you go out without your head?"

This exchange impressed on me that if I was to appreciate sowei masks from a Mende perspective in the same way that I had been taught to appreciate a Botticelli painting by understanding fifteenth-century religious observances, neo-Platonism, and aesthetic ideals, it would be necessary to attend both to the moments when translation proved difficult and to the synesthetic experience of the total performance. It was one of many transformative moments in my practice as an art historian that I owe to dialogue with members of contemporary indigenous communities. Cumulatively, such encounters have led to a conviction that for both cognitive and ethical reasons, the goal of achieving emic, or insider, understanding trumps-although does not necessarily preclude-the subsidiary formal and connoisseurial pleasures of looking at "heads." I have never since been able to look at a museum installation in which a sowei mask has been stripped bare of her raffia, white head tie, protective amulets, jewelry, and black body costume without feeling that a violation has taken place-a voyeuristic stripping bare, an amputation.

Ndoli jowei masker and Sande Society officials Field photograph, 1972.

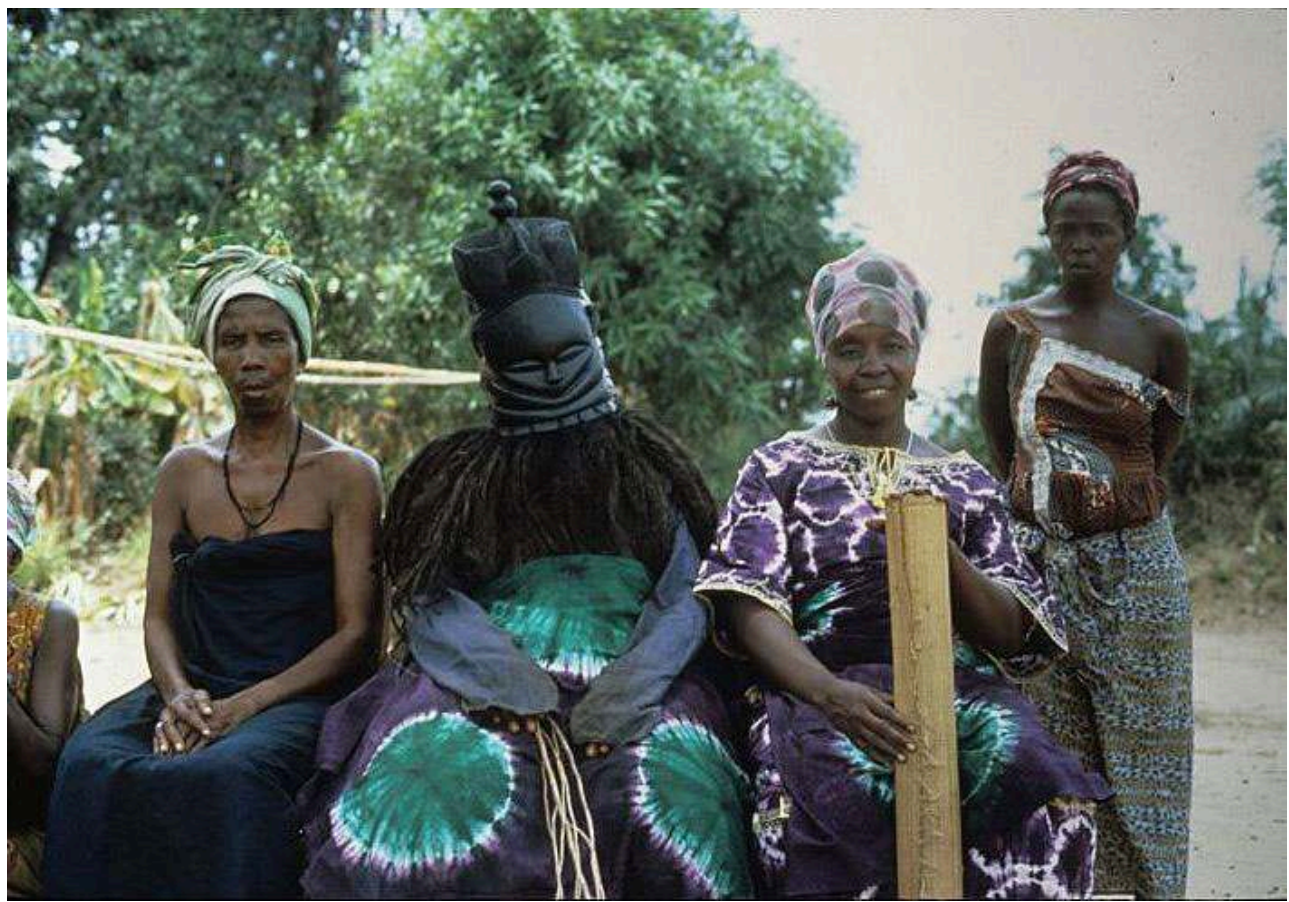

Photograph by Ruth Phillips.

For anyone with a training in art history, such an apprehension is inevitably also informed by Marcel Duchamp's fundamental insight that the Western system of art and museums operates as a machine for the production of economies of commodification and desire while at the same time preventing the fulfillment of those desires. Like the Bride in The Bride Stripped Bare by her Bachelors, Even, the African mask, displayed as a bare headpiece, cannot satisfy the viewer's hunger to possess the Other. Decapitated 
and stripped, the mask fatally frustrates access to the knowledge of the Other which is at the heart of the satisfaction of desire. The universalizing process of formalist appreciation that is imposed under the sign of modernist primitivism occludes localized identities, denatures the exotic, and reduces it to sameness. Equally importantly, such modernist installation strategies prevent viewers from recognizing the historical and contemporary networks of interconnection amongst world cultureswhether they be networks of artistic exchange or the underlying political and economic processes which have delivered up exotic artifacts to the Western gaze. My example of masks from Sierra Leone is particularly compelling in this respect, because the diamond-driven violence suffered by its peoples lends to the words "amputation" and "stripping" a literal and tragic resonance. The ethical problem is, however, general, and urgent in this era of speeded up global flows of people, capital, images, and things.

5 My small epiphany in West Africa is paralleled by the experiences of many other historians of non-Western art who have gone "into the field" both in distant countries and in their own back yards. In the academy, the transformative power of dialogic encounter has produced a remarkable new art-historical and anthropological literature about non-Western arts. In the museum, dialogue with members of originating communities, activated by post-colonial politics and contestations, has resulted in innovative new collaborative practices, especially in settler societies such as Canada, Australia, New Zealand, and the United States. Museums have begun to reverse past processes of stripping away, to revise modernist notions of authenticity, and to alter standard Western practices of conservation. The example of masks is, again, emblematic, as demonstrated by three representative examples of restoration projects that have taken place during the past decade or so. At the Fennimore House Museum in Cooperstown, New York, Yupik artist and performer Chuna McIntyre has replaced the feathers and other elements that were lost decades earlier from the Yu'pik masks so beloved of the surrealists and other modernist artists. The University of British Columbia's Museum of Anthropology and the Royal British Columbia Museum regularly lend old masks in their collections for use in potlatches and other events, allowing artists to add new cedar bark fringes and even to repaint them so that they can be returned to a state appropriate for performance. A conservator at the Metropolitan Museum of Art worked with art historian Frederick Lamp, a specialist in Baga art from Guinea, to make a new raffia and fabric body costume for a Baga D'mba mask-another African genre canonized by the modernist taste culture-which is displayed in its Rockefeller wing.

6 Museum installations of indigenous arts have also changed, although in ways that are more uneven and difficult to characterize. There has been a notable merging of the modernist display paradigms of art and artifact; art museums such as the Metropolitan increasingly provide extended labels, maps, and contextual photos that instruct viewers about the meaning of iconographic motifs and ritual contexts, while anthropology museums regularly exhibit contemporary art as a way to incorporate indigenous perspectives on history and culture and as cultural artifacts that evidence both living world views and participation in international art markets. Yet in other museums, such as the Louvre's Pavillon des Sessions, the old paradigms seem to have reasserted themselves in particularly pure forms that seem strangely reactionary following more than two decades of deconstruction and postcolonial critique. 
7 In the remainder of this paper I will interrogate this early twentieth-first century tension between hybridity and purity in three different ways. I will look briefly at the hybrid relationship between art history and anthropology which, as I will argue, has not only been increasingly evident in recent years, but was also present in the formative phases of the two disciplines. I will then turn to Bruno Latour's theorization of hybridity and his concepts of imbroglio and translation in order to urge their explanatory force in rethinking the museum representation of indigenous arts in the twenty-first century. In the last section of the paper I will discuss two current exhibitions of African and Pacific Islands art that, in my view, instantiate the attention to hybridity and networks that Latour advocates.

\section{Art history and anthropology-always already hybrid}

8 The relationship between art history and anthropology has most often been represented as a dialectical opposition: art historians focus on works of art, defined as products of high culture, in order to promote aesthetic appreciation and experience, while anthropologists study material culture as evidence of cultural beliefs and technologies and as mechanisms for social reproduction in order to promote cognitive understandings of the ways of life of entire social groups. This has, in my view, always been something of a false dichotomy, for in their modernist phases both disciplines drew on a common repertoire of aesthetic and scientific constructs in order to contribute to evolutionist and progressivist meta-narratives of human history. Both adopted a comparative methodology based on visual description and analysis that was derived from natural science and for which collections of material objects and visual images were essential. Both judged value in terms of similar standards of aesthetic quality grounded in Kantian aesthetics, and both imposed a characteristically Western hierarchy of fine and applied arts on objects produced in other times and by other cultures. In the early twentieth-century, through the parallel projects of Franz Boas and Alois Riegl, both disciplines also began to move toward more historically contingent and relativist modes of analysis and understanding.

9 It is not accidental that the modernist paradigms of art and artifact were most rigidly imposed on indigenous art forms during the middle decades of the twentieth century, for during this period, the project of historical and cultural contextualization common to art historians and cultural anthropologists was suspended. Academic anthropologists moved away from the study of material culture and the anthropology of art, and art historians adhered to their traditional focus on the European tradition and "Great Civilizations." By default, the representation of indigenous arts was left largely to a third discursive community, made up of modernist artists and critics whose deep appreciation of Primitive Art was narrowly defined by their formalist aesthetic concerns and their disenchantment with industrial modernity.

The re-engagement of art history and anthropology in the 1980s was stimulated by a number of interrelated political, economic, and social movements of the postwar period, including the dismantling of colonial empires, the civil- and human-rights movements, identity politics, the growing demographic pluralism of Western nations, and economic and cultural globalization. Arguably, the growing cultural inclusivity of art history and its renewed interest in the social history of art, the revival of material culture studies and the anthropology of art, the interest of both scholarly communities 
in contact histories, and the emergence of new interdisciplinary fields such as visual studies and critical museology all respond to these global developments.

11 In keeping with these trends, anthropologists have returned to museum storerooms and archives and study the circulation of "art" across cultures. Art historians study a broader range of world art traditions and make use of anthropological theory and fieldwork methods. It is often difficult to tell the difference, at least in theory, among visual anthropologists, anthropologists of art, practitioners of the social history of art, and art historians who define their field as visual studies. In their renewed hybridity, art historians and anthropologists are today working out old methodological and conceptual problems within the new frames of post-colonialism, pluralism, transnationalism, and globalization.

\section{We have never been modern: hybridity and imbroglio}

What, then, has been the parallel history of art and anthropology museums which, in their origins, were controlled by academic disciplinary formations? It is a notable feature of the late twentieth century that a great many of the most ambitious exhibitions of indigenous arts have been attended by controversy and intense critical debates which have been well rehearsed in the critical literature. A partial list would include the Museum of Modern Art's Primitivism and Twentieth-Century Art (1984), the Glenbow Museum's The Spirit Sings (1988), the Royal Ontario Museum's Into the Heart of Africa (1989), the Arts Council of Great Britain's The Other Story (1990), the Centre Pompidou's Magiciens de la Terre (1989), the US National Gallery of Art's Circa 1492 (1992), the permanent installations of the Smithsonian's new National Museum of the American Indian (2003), and, most recently, the Musée du Quai Branly (2005).

Each of these museological projects overflowed its boundaries into realms of politics, ethics, and practice to which it had initially seemed unrelated. This kind of excess has been characterized by Bruno Latour, the historian and philosopher of science and cofounder of Actor Network Theory (ANT), as a sign of the breakdown of the categorical separations imposed by modernism. Some of Latour's key concepts seem very useful for our present problem. In particular, I want to make use of his notion of "imbroglio," defined in his 1991 book We Have Never Been Modern as an entanglement of unrelated phenomena. Like Latour's imbroglios of phenomena of the scientific and the social that have been understood as separable and discrete, the museum dilemmas of recent years often occur when categorical distinctions between art and non-art or the West and the rest are revealed as always already fictive.

Latour's understanding of the modern both predicts and explains these museum dilemmas. "The proliferation of hybrids,"he writes, "has saturated the constitutional framework of the moderns" [italics original]. In other words, such blurrings and convergences indicate that our categories can no longer contain the accumulated contradictions bred by their own fictiveness. As he notes, "when the word 'modern,' 'modernization,' or 'modernity' appears, we are defining, by contrast, an archaic and stable past. Furthermore, the word is always being thrown into the middle of a fight, in a quarrel where there are winners and losers." But the response he advocates goes further, for in order to reconnect that which has been severed by the modern "work of purification" we must substitute what he calls a "work of translation" in which we 
engage actively in identifying those networks which have, all along, connected the multifarious phenomena of the world. In his words:

[T] he word 'modern' designates two sets of entirely different practices which must remain distinct if they are to remain effective, but have recently begun to be confused. The first set of practices, by 'translation', creates mixtures between entirely new types of beings, hybrids of nature and culture. The second, by 'purification', creates two entirely distinct ontological zones: that of human beings on the one hand; that of nonhumans on the other. ... The first set corresponds to what I have called networks; the second to what I shall call the modern critical stance.

As a theorist of science studies, Latour's primary focus here is on the relationship processes purported to belong to incommensurable realms of science and society. I propose a parallel necessity for the work of critical museology, for just as the environmental crisis has made urgent the reconsideration of the nature/culture dichotomy, so has the challenge of learning to live in increasingly pluralist societies made it necessary to revisit the art/culture divide. Indeed, from the perspective of ANT, the science/society and Western/non-Western art and culture issues are themselves part of a large network, for it often precisely the categorical division of nature from culture that indigenous advocates seek to alter in museum representations. If in the past, the museum has served as one of modernity's key tools of separation and purification, it is, then, today called upon to serve as a site where the networks that link complex and apparently heterogeneous social, political, economic, and natural events are revealed rather than concealed

\section{Networking the object, and the twenty-first century exhibition}

Latour's critique of modernity has not only useful explanatory force in helping us to understand the debates that regularly explode around museum representations of nonWestern phenomena, but also indicates ways in which museums might work with hybridity rather than suppressing or occluding its presence. Such a project would require museums to make evident the way in which categories are networked-for example, the interconnectedness of art history and anthropology and the economic and other relationships among the peoples of the "West" and the "non-West" that have been present for centuries. As I learned from the experience of fieldwork, the key is to focus on the processes of translation. Cognitively, attending to the concepts which are most difficult to translate reveals the spaces between different world views that need to be bridged in order to achieve dialogue. Ethically, acts of translation among the different systems of meaning-nature, culture, art, economic exchange-enable us to identify the networks of apparently heterogeneous social, political, economic, and natural events which link peoples together across distances great and small. As noted, translation is a key concept of ANT theory. As John Law has written, it represents the process by which heterogeneous actors form into networks. "'Translation," he writes, "is a verb which implies transformation and the possibility of equivalence, the possibility that one thing (for example an actor) may stand for another (for instance a network)." By focusing on the activity of translation, as Law and Latour recommend, we may be better able to re-position museum representations within complex networks of historical and contemporary cultural interaction rather than mystifying them. 

would like to conclude this paper by discussing two exhibitions focusing on masks and masquerades. Both, in my view, work with hybridity by attending to translation in the senses I have been advocating. The first is a small temporary exhibit entitled The Village is Tilting: Dancing AIDS in Malawi, which opened in January 2006 at the University of British Columbia Museum of Anthropology in Vancouver. The second is a permanent installation at the National Museum of Australia in Canberra, entitled Dhari a Krar: Headdresses and Masks from the Torres Strait, which opened in 2005. Both are relatively small exhibitions, created with modest budgets. Both insist on the dynamic nature of masquerade traditions as expressive modes that adapt to the changing conditions of life of indigenous people in the contemporary world, rather than freezing them in a past time of cultural purity or fetishizing them as objects of desire. Both exhibitions, furthermore, make the masks available for aesthetic appreciation as products of an individual carver's skill and imagination while also representing them contextually as masquerades comprised of multimedia assemblages of carvings, textiles, dramatic impersonation, sound, and dance.

The Village is Tilting was curated by Douglas Curran, a photographer who has spent ten years visiting Malawi to create a comprehensive photographic documentation of the Gule Wamkulu,or Great Dance of the Chewa people. The exhibition juxtaposes his largescale photographs with mask headpieces and costumes. As the title of the exhibition indicates, its thematic focus is the way in which the Chewa address the AIDS pandemic and its devastating impact on their lives through their masquerade traditions. A video monitor placed at the entrance to the exhibition introduces the theme with a series of short statements by Chewa people. Visitors then enter down a ramp lined with a semitransparent fabric wall through which the masks appear as spectral presences. Excerpts from interviews with Chewa consultants are printed on the fabric, introducing the historical, cosmological, and causal framework through which Chewa villagers speak about AIDS. "When the men were going to work in the mines, this is when this disease started to come to us," states Mai Karonga. "We who don't listen, descend to the silence of our ancestors long ago. AIDS, NO! There is AIDS." "There is the slippery slope to the silence," says Luciano Zagwazatha, a man from another village. Mai Alphonsina Kumilambe elaborates, stating: "Men, women, and boys and girls are not following the rules of life set out by our ancestors [...] today no young girl runs away from a man."

The text panels in the exhibition provides an ethnographic account of theGule Wamkuluand the access provided by the masked spirits, or nyau, to the spirits of the ancestors and their power over fertility and life. The texts also recall the attempts of colonial administrators to ban the Great Dance as an obscene "national evil," and affirm the adaptive capacity of the masquerades to reinforce positive social values and trans-generational continuity. The maskers, we are told,

dance stories old and new that reinforce the consensus on the family and community values that are the cornerstone of Chewa identity. Failure to recognize the role of the spirits [...] the Chewa believe, leads to disruption and a breakdown of the community.

As the AIDS virus has permeated their society, the forms of the Chewa spirits have been regenerated again, providing new contemporary frameworks through which to understand the broader social implications and responses to the pandemic. 
Other text panels interpret unfamiliar artistic materials by explaining their significance in Chewa cosmology:

Madzi ndi mayo, the Chewa say, "water is life," an idea reflected in key elements of nyau practice. [...] The idea is borne out by the materials used to create the masks. Water-softened bamboo is bent for ribs, while wetted palm leaves are fashioned into heads and jaws of 30 foot long spirit animals. This sacred application of mud details for the eyes and face is equivalent to kumwtsera, to give a drink, and the act of mudding the limbs and goodies of the dancers is kusamba, to wash.

Both traditional masquerade characters such as "Chadzunda, The old deaf man/The chief," who represents ideals of dignity and modesty, and "Akupha Aonongo, The killers are destroyers" are presented and their attributes explained. Akupha exemplifies the Chewa "anti-aesthetic": his "appearance indicates he is a carrier. His face is not smooth and well-oiled as is the Chewa ideal: instead, his dusty, ashen skin is delineated with many wrinkles, and atop his head is a tumor."

The effectiveness of the exhibition results, as always, from the success of the designer, Skooker Broome, in creating an installation that expresses its central thematic in visual and spatial terms. The walls are painted a deep rusty red, the color of blood, in keeping with the aura of danger and power invoked both by AIDS and the Gule Wamkulu. This use of color and the dramatic spotlighting of the individual masks also intensify the sense of enclosure and drama. The juxtapositions of the masks with Curran's largescale photographic panels and triptychs evoke a sense of human scale and interaction, further enhanced by a video of masquerade performances in Chewa villages. Each assemblage of carved headpiece, costume, and photographs is given sufficient space to be appreciated as a unique ensemble; design and installation combine to position viewers as spectators of dramatic performances.

A similar emphasis on context and theatricality characterizes the National Museum of Australia's Dhari a Krar: Headdresses and Masks from the Torres Strait, and it, too, emphasizes the role of masquerade traditions in mediating historical and contemporary change. The exhibition is the result of a collaboration between the museum's curator, Anna Edmundson, and two Torres Strait Islanders who are also museum professionals. Brian Robinson, an artist and a curator at the Cairns Regional Gallery, originated the idea for the exhibition while an intern at the museum, and Carly Jia was brought in to liaise with community members in the Torres Straits. Jia commissioned new masks for the exhibition and the Museum's permanent collection and also developed public programming.

Nineteenth-century Torres Strait masks are canonical objects of Primitive Art. The famous tortoise shell and wooden masks left the islands in the late nineteenth and early twentieth century following the "Coming of the Light" in 1871, when missionaries arrived in the Torres Strait and converted the people to Christianity. Today, none of these old masks remains in Torres Strait communities. Rather, masquerade traditions continued to evolve and adapt in response to new spiritual and political needs. Dhari a Krar is remarkable for the clarity with which it explains the relationship of the older masks to these more recent masquerade traditions, and, in so doing, demystifies the "rare art tradition," to use Joseph Alsop's phrase, of Primitive Art. We learn that masquerades and headdresses remain important symbols of distinct local identities within the Torres Strait region and also serve as a key site for the reenactment and preservation of historical memory. The opening panel states (both in English and in Kala Lagaw Ya, Torres Strait Islander Western language) that headdresses and masks 
have distinct local histories and styles within the islands and that they are today "a source of ongoing identity and pride for Islander people."

The texts are explicit about the way in which masquerade traditions were adapted after the coming of Christianity. A text panel on "Old-fashioned Dance" states:

The arrival of the London Missionary Society on Erub (Darnley) Island in 1871 heralded a number of changes to Torres Strait dance and dance artefacts. While many cultural practices were discouraged, some traditional dances were deliberately maintained as part of secular celebrations.

Dances adhering more strictly to pre-Christian styles are known as 'old-fashioned dance'. Dances incorporating newer elements (such as Polynesian dance styles introduced by missionaries in the late 19th century) are known as ailan dans (island dance.)

27 In explaining how masks and headdresses reflect trade in the islands the exhibition also works to correct widely held dismissal of hybrid forms as inauthentic and, in the process, provides a striking example of how stripping away these added elements denatures the local identity and artistic content of a mask. "Through trade, Islanders acquire the bases for the masks themselves," the panel on "Trade" states. "Wooden masks known as mawa or buk were traded from Papua New Guinea in an undecorated state. Torres Strait people added ochre designs, human hair, feathers, fibres and seeds." A piece of information that also suggests in a highly graphic way how stripping away these added elements denatures the local identity and artistic content of a mask.

Another important way in which masquerades facilitate the realities of demographic mobility and migration in the Pacific Islands is stated in the panel on "Dance and Innovation":

Unlike ceremonial dances, Torres Strait secular dances have always been innovative in their choreography and costume. From the mid 1800s the establishment of missions and the pearling industry brought people from around the globe including Japanese, Malays, Filipinos, Micronesians, Polynesians and Europeans. Torres Strait Islanders took advantage of this mix of cultures to create new repertoires of songs and dances. Today Torres Strait Islander dancers continue to draw on a diverse range of influences.

As in the UBC Museum of Anthropology's Chewa exhibition the design of the National Museum of Australia's exhibition communicates its messages not only through words, but also through the choices of color, lighting, visual aids, and spatial arrangement. When the curators engaged Merrima Design of Brisbane (whose head is a Torres Strait Islander), they provided a clear brief to the designer. "We wanted an "art hang," Edmonson explains, "whose simplicity would not distract from the masks and headdresses on display. The design would, however, convey the drama of traditional masquerades performed in jungle clearings when, during initiation, masked beings would appear suddenly among the trees, impressing the initiates with their mystery and power.

For visitors to the exhibition, the core of the exhibit is the large screen on which masquerade performances are projected so that the dancers appear close to life size. The video projection activates the mask headpieces displayed on the walls and enables visitors to become spectators at a virtual performance. Equally importantly, the contemporaneity of the experience makes clear that the masquerade traditionstransformed by Torres Strait Islanders' success in using this art form to address the enormous changes in spiritual belief and the political and demographic makeup of their society of the past century-is a living art form that will continue to grow and 
evolve. The walls and cases are painted black, allowing both old and new masks installed in cases to be seen and appreciated for their formal qualities. But as the visitor views them, the music of performance fills the room, emanating from a large video of masquerade and dance performances on a stage, made especially for the exhibition. Like the Curran photographs in The Village is Tilting, these images are close to life-size. In the dark room, the electric glow, color, movement, and sound of the video draw visitors to sit and watch the dancers. As at the UBC Museum of Anthropology, they become spectators at a virtual performance.

Both of these exhibitions make clear that it is not necessary to choose between formal appreciation and contextual understanding, or between knowledge of the historical evolution of an art form and its relevance to contemporary societies. Rather, both successfully translate between the familiar rigor of the Western art gallery's attention to form and the performative aesthetic and cognitive understandings of the originating communities. On a didactic level, both also reveal the global networks of circulation which have carried Christianity, viruses, human diasporas, money, political powerand masks-back and forth across the globe for over a century. To do less in contemporary exhibitions is to fail to come to grips with the most important challenge that public museums have faced since they emerged as key institutions of geopolitical and historical consciousness and aesthetic experience at the beginning of the nineteenth century. We must find better ways to relish difference without homogenizing it through the very act of recognition, and to respect separateness while at the same time insisting on interconnection.

\section{BIBLIOGRAPHIE}

Alsop 1982: Alsop, Joseph. The Rare Art Traditions: The History of Art Collecting and its Linked Phenomena Wherever These Have Appeared. New York: Harper \& Row, 1982.

Buchloh 1989: Buchloh, Benjamin H.D. “The Whole Earth Show: An Interview with Jean-Hubert Martin." Art in America (May 1989).

Clifford 1988: Clifford, James. "Histories of the Tribal and the Modern." In The Predicament of Culture. Cambridge, MA: Harvard University Press, 1988.

Cole 1970: Cole, Herbert. African Arts of Transformation. Santa Barbara, CA: The Art Galleries, University of California, 1970,

Curran 1999: Curran, Douglas. "Nyau Mask and Ritual.” African Arts32, 3 (Autumn 1999): 68-78.

Dominguez 1992: Dominguez, Virginia. "Invoking Culture: The Messy Side of Cultural Politics." The South Atlantic Quarterly 91, 1 (1992): 19-42.

Foster 1985: Foster, Hal. “The Primitive Unconscious of Modern Art, or White Skin Black Masks." In Foster, Hal, ed. Recodings: Art, Spectacle, Cultural Politics. Seattle: Bay Press, 1985.

Ginzburg 1989: Ginzburg, Carlo. "Clues, Roots of an Evidential Paradigm.” In his Clues, Myths and the Historical Method. Baltimore: Johns Hopkins University Press, 1989. 
Latour 1991: Latour, Bruno. We Have Never Been Modern. Translated by Catherine Porter. Cambridge, MA: Harvard University Press, 1993.

Law 1992: Law, John. "Notes on the Theory of the Actor Network: Ordering, Strategy and Heterogeneity." http://www.lancs.ac.uk/fass/sociology/papers/law-notes-on-ant.pdf (accessed March 2008). (Also published in Systems Practice 5: 379-93.)

Marcus and Myers 1995: Marcus, George E. and Fred R. Myers, eds. The Traffic in Culture: Refiguring Art and Anthropology. Berkeley: University of California Press, 1995.

Morphy 2007: Morphy, Howard. Becoming Art: Exploring Cross-Cultural Categories. New York: Berg, 2007.

Myers 2002: Myers, Fred R. Painting Culture: The Making of an Aboriginal High Art. Durham, NC: Duke University Press, 2002.

Phillips 2007: Phillips, Ruth B. "The Museum of Art-thropology: Twenty-First Century Imbroglios." Res: Anthropology and Aesthetics 52 (Autumn 2007): 8-19.

Thomas 1991: Thomas, Nicholas. Entangled Objects: Exchange, Material Culture, and Colonialism in the Pacific. Cambridge, MA: Harvard University Press, 1991.

Westermann 2004: Westermann, Mariet, ed. Anthropologies of Art. New Haven: Yale University Press and Clark Art Institute, 2004.

Jones 1993: Jones, Anna Laura. "Exploding Canons: The Anthropology of Museums." Annual Review of Anthropology 222 (1993): 201-20.

Butler 2007: Butler, Shelley Ruth. Contested Representations: Into the Heart of Africa. Peterborough, ON: Broadview Press, 2007.

Lonetree and Cobb 2008: Lonetree, Amy and Amanda Cobb, eds.The National Museum of the American Indian: Critical Conversations.Lincoln, NB: University of Nebraska Press, 2008.

\section{RÉSUMÉS}

This paper addresses the new hybridities that are emerging as 20th century installation paradigms of art and artifact are re-deployed in 21st century-museum installations of nonWestern art. After more than two decades of sustained deconstruction and critique, the resurgent vitality of these modernist representational tropes can seem startling both to art historians and to anthropologists. Many scholars in both disciplines have come to view these paradigms as themselves artifacts of a modernist museology that has been superceded by more socially embedded and processual approaches to interpretation.

As a point of departure for my discussion, I invoke the insights into industrialization, commoditization, purification, and voyeuristic pleasure advanced by Marcel Duchamp in his The Bride Stripped Bare by Her Bachelors, Even (Large Glass) of 1915-23. His critique, in conjunction with later art historical and anthropological theorizations offered by Janet Wolff and Igor Kopytoff, provides useful tools for understanding and problematizing the continuing impulse to 'strip bare' non-Western museum objects. I argue that in the 21st century both art historians and anthropologists must develop ethically informed practices that can respond to the global environmental, social, and political convulsions that threaten members of both Western and non-Western societies. Drawing on Bruno Latour's notion of the 'imbroglio,' I urge the necessity of incorporating an awareness of hybridity and networks of interconnection into museum representation. As an example of what such hybrid installations might look like, I discuss a 
recent exhibition of Chewa masks at the University of British Columbia Museum of Anthropology.

INDEX

Keywords : Actor Network Theory, African masks, hybridity, museum installation

\section{AUTEUR}

\section{RUTH B. PHILLIPS}

Ruth B. Phillips is Canada Research Chair and Professor of Art History at Carleton University in Ottawa, Canada. She is a specialist in the arts of Canadian indigenous peoples and the author of several books including Trading Identities: The Souvenir in Native North American Arts from the Northeast, 1700-1900, and Native North American Art (with Janet Catherine Berlo). She also writes on critical museology and served as director of the University of British Columbia Museum of Anthropology from 1997 to 2002. 